\title{
A importânCia do café Para São Tomé e PrínCIPE FRENTE À PROIBIÇÃo do COMÉRCIO DE ESCRAVIZADOS PELA INGLATERRA
}

\author{
Alan de Carvalho Souza (D) \\ Universidade de Lisboa
}

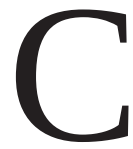

onsiderado como centro de “experimentação” da colonização, São Tomé e Príncipe teve o povoamento de seu território desabitado realizado por dois grupos: europeus e africanos escravizados, originando, mais tarde, uma população mestiça e livre. ${ }^{1} \mathrm{O}$ arquipélago localizado no Golfo da Guiné (Figura 1) ganhou destaque econômico com a cultura da cana-de-açúcar ainda no século $\mathrm{XVI}^{2}$ e com a reexportação de escravizados, ${ }^{3}$ que até os anos finais da década de $1820^{4}$ apresentava-se como a principal receita alfandegária.

Durante a primeira metade do século XIX, o empobrecimento era constantemente relatado nas comunicações entre os governadores do arquipélago com a metrópole. Mas o declínio já era noticiado desde o

1 A data exata do “achamento” do arquipélago não é conhecida. Estima-se que o fato ocorreu em 1471 na ilha de São Tomé, e 1472 na ilha de Príncipe. Isabel Castro Henriques, São Tomé e Príncipe: a invenção de uma sociedade, Lisboa: Vega, 2000, pp. 22-23. No ano de 1515 foi concedida a alforria às mães escravas e aos filhos mestiços. Em 1517 outro decreto real libertou aqueles escravizados que chegaram com os primeiros colonos. Gerhard Seibert, "Colonialismo em São Tomé e Príncipe: hierarquização, classificação e segregação da vida social”, Anuário Antropológico, v. 2 (2015), pp. 99-120.

2 Henriques, São Tomé e Príncipe, p. 39 e p. 64.

3 Arlindo Manuel Caldeira, "Mestiçagem, estratégia de casamento e propriedade feminina no arquipélago de São Tomé e Príncipe nos séculos XVI, XVII e XVIII”, Arquipélago, v. 11-12, n. 2 (2007-2008), pp. 49-72.

4 De acordo com os mapas de exportação de São Tomé e Príncipe, o café foi responsável por 59,41\% de toda a exportação do ano de 1829. Arquivo Histórico Ultramarino (AHU), Lisboa, Conselho Ultramarino (CU), Avulsos, São Tomé e Príncipe (STP), cx. 58, doc. 11, Mapas da Receita e Despesa dos Cofres da Fazenda Real destas Ilhas, Ilha do Príncipe, 20 jan. 1830. 
Seiscentos. Francisco Tenreiro, ao descrever o estado de "decadência” da ilha de São Tomé no século XVII, afirmou que "a governação central embaraçada com a colonização do Brasil, numa política de autêntico sacrifício das posições africanas” somada à falta de recursos "não tinha possibilidades de acudir às gentes de São Tomé”. ${ }^{5}$

Figura 1

Mapa de São Tomé e Príncipe

A R.D. DE S. TOND E PRTNCIPE NO WINDO E NO GOLFO DA GUINSS.

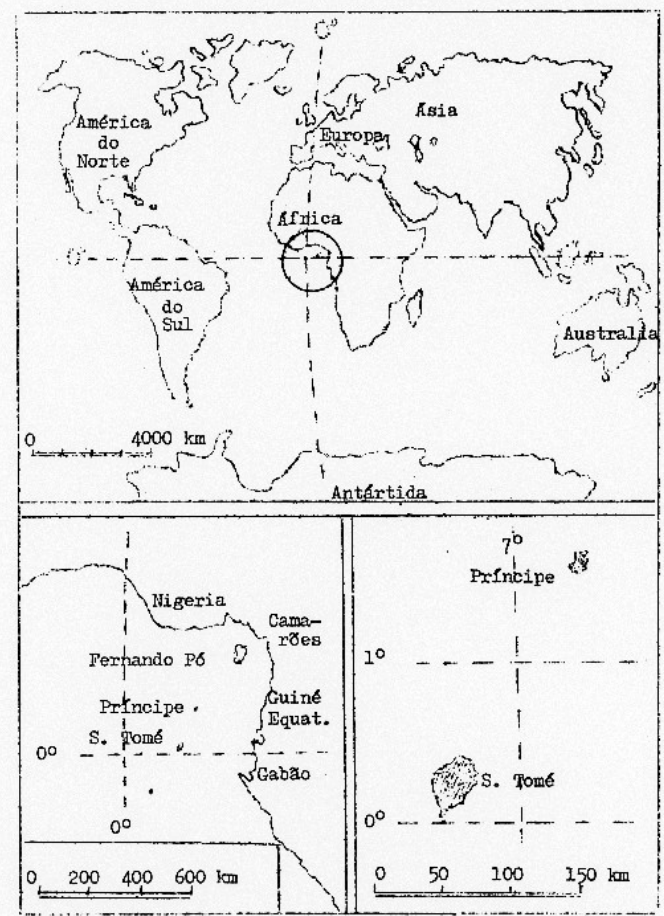

Fonte: Gabinete de Estudos e Pesquisas Pedagógicas, Atlas Nacional de Apoio, São Tomé: Ministério de Educação e Cultura da RDSTP, 1983. Esse e outros mapas podem ser consultados em Associação Caué, Atlas de São Tomé e Príncipe $\boldsymbol{~ ש . ~ A s ~ d i m e n s o ̃ e s : ~ i l h a ~ d e ~ S a ̃ o ~ T o m e ́ ~ c o m ~} 859$ km² e ilha do Príncipe com $142 \mathrm{~km}^{2}$.

5 Francisco Tenreiro, A ilha de S. Tomé, Lisboa: Junta de Investigação do Ultramar, 1961, pp. 75-76. 
A situação se agravou a partir da ocupação mais efetiva da colônia portuguesa na América e, principalmente, com a produção de açúcar de melhor qualidade, que ocasionou a emigração de muitos envolvidos no fabrico da especiaria para a "nova colônia”. Se os produtores açucareiros da possessão emigraram para o Brasil levando seus engenhos e mestres, séculos depois, em finais do XVIII, o Brasil exportaria para o arquipélago culturas como café e cacau, ${ }^{6}$ que durante parte da primeira metade do Oitocentos ganhariam destaque na exportação, com o café tornando-se o principal produto agrícola das ilhas.

O cultivo do café, inicialmente, sofreu resistência de diferentes partes, do governador, de escravizados, de africanos livres e de mulatos. ${ }^{7}$ Entretanto, o café e, posteriormente, o cacau $^{8}$ foram os responsáveis pelo renascimento econômico do arquipélago gerando a "prosperidade que havia desaparecido". ${ }^{9}$ No início do Oitocentos o café foi "uma das

6 Se o café foi implantado no século XVIII, a cultura do cacau, que se tornaria a principal exportação do arquipélago durante a segunda metade do século XIX, só foi estabelecida no início do Oitocentos a partir da ilha de Príncipe. Yoso José da Silva, "O desenvolvimento econômico: um estudo sobre a evolução econômica de São Tomé e Príncipe do período colonial ao período pós-colonial”, Dissertação (Mestrado em Administração), Universidade Federal de Pernambuco, Recife, 2009, p. 28.

7 Provavelmente os mulatos pertenciam à categoria dos autóctones, pois, de acordo com Isabel Castro Henriques, tratava-se “de mulatos amados pelos pais brancos”. Henriques, São Tomé e Príncipe, pp. 132-133.

8 Sobre o crescimento vertiginoso da cultura do cacau, por conseguinte, da exportação, ver Sandra Kiesow, "Cocoa Culture on São Tomé and Príncipe: The Rise and Fall of Cocoa on the Islands in the Nineteenth and Twentieth Centuries", Agricultural History, v. 91, n. 1 (2017), pp. 55-77 do. Sobre o fornecimento de mão de obra para a lavoura do cacau com o objetivo de torná-la mais competitiva no mercado mundial durante o período de 1853 a 1903, ver Nátalia Pedro da Costa Umbelina, "Les îles São Tomé et Príncipe (1853-1903): de l'abolition de l'esclavage à la généralisation des travailleurs sous contrat, les Serviçaes”, Tese (Doutorado em História), Université de Provence, Aix-en-Provence, 2007. Sobre o colapso final da produção do cacau, ver Jędrzej George Frynas, Geoffrey Wood e Ricardo M. S. Soares de Oliveira, "Business and Politics in São Tomé e Príncipe: From Cocoa Monoculture to Petro-State”, African Affairs, v. 102, n. 406 (2003), pp. 51-80 ש.

9 Henriques, São Tomé e Príncipe, p. 78. 
alavancas impulsionadoras da renovação agrária”, ${ }^{10}$ o que demonstra a importância alcançada pela cultura na possessão.

Não diferente do que aconteceu nas colônias francesa, holandesa e portuguesa na margem oposta do Atlântico, em São Tomé e Príncipe tratou-se também de uma agricultura baseada no trabalho escravizado. A lavra cafeeira no arquipélago beneficiou-se, segundo Carlos Agostinho das Neves, da existência de uma infraestrutura escrava ou impulsionada pelo tráfico. ${ }^{11}$

Composto por colonos europeus e os chamados "brancos da terra", ${ }^{12}$ grupo fundiário do arquipélago disputava entre si o protagonismo ${ }^{13}$ e controlava o "resgate de escravizados" que seriam aplicados na agricultura. Os "brancos da terra", também conhecidos como as "filhas das ilhas", mestiças ou "brancas da terra”, pertenciam "a grupos familiares há muito enraizados no arquipélago”. ${ }^{14}$ De qualquer modo, esse grupo destacava-se no resgate de escravizados e como proprietário de terras e escravos. ${ }^{15}$

Se a elite local era "moldada" pela disputa de espaço no resgate de escravizados e o arquipélago era abastecido com gêneros de primeira necessidade pelas embarcações estrangeiras, a proibição inglesa ao comércio de escravizados foi uma das responsáveis pela retração da atividade comercial. ${ }^{16}$ Naquele momento, mesmo sem apresentar maiores

10 Tenreiro, A ilha de S. Tomé, p. 217.

11 Carlos Agostinho Neves, S. Tomé e Príncipe na segunda metade do séc. XVIII, Lisboa: Instituto de História de Além-Mar, 1989, p. 79.

12 Nomenclatura que não tinha necessariamente a ver com a cor da pele. Caldeira, “Mestiçagem”, p. 56.

13 Henriques, São Tomé e Príncipe, pp. 132-133.

14 Caldeira, “Mestiçagem”, p. 71.

15 Referência à argumentação apresentada por João Fragoso em que procurou analisar os vários tipos e formas de alianças entre os ditos "nobres” e também entre pessoas de grupo social considerado "inferior”. João Fragoso, “A nobreza vive em bandos: a economia política das melhores famílias da terra do Rio de Janeiro, século XVII”, Tempo, v. 8, n. 15 (2003), pp. 11-35.

16 Em 1807 a Inglaterra proibiu o comércio de escravizados entre as colônias britânicas na África e nas Américas. 
resultados, o café, em razão de sua qualidade, era o produto capaz de manter parte do interesse estrangeiro na possessão. Entretanto, em janeiro de 1808 a escassez sentia-se com a queda acentuada nos "ramos de comércio, agricultura, e que se acha[va] quase extinto". ${ }^{17}$

Outro ato que prejudicou economicamente a região e acentuou a diminuição do número de embarcações no arquipélago foi a isenção de “tocar” na possessão concedida pela Coroa portuguesa a todos os mestres de navios do Brasil que comercializavam na Costa da Mina, desde que fossem recolhidos os direitos aos portos a que pertencem, ou seja, aos portos onde foram realizadas as barganhas comerciais. ${ }^{18} \mathrm{O}$ ofício do governador das ilhas que apresentava as consequências da proibição inglesa e da concessão feita aos navios do Brasil foi datado em $1^{\circ}$ de abril de 1809 e ponderou a desobrigação da ancoragem das embarcações como o mais

17 AHU CU STP, cx. 42, Ofício resposta de 24 de setembro de 1808 ao Real Aviso de 16 de março do mesmo ano, Ilha do Príncipe, 24 set. 1808. A média anual de arrecadação sobre a comércio de escravizados em São Tomé e Príncipe foi de 14:106\$174 réis (período de 1809 a 1814, exceto o ano de 1811); já para o recorte de 1815 a 1817 , a receita foi de 8:767\$307 réis. AHU CU STP, cx. 44, doc. 21, Mapas da Receita e Despesa dos Cofres da Fazenda Real destas Ilhas, Ilha do Príncipe, 30 jun. 1810; cx. 45, doc. 16, Mapas da Receita e Despesa dos Cofres da Fazenda Real destas Ilhas, Ilha de São Tomé, 20 maio 1811; cx. 48, doc. 4, Mapas da Receita e Despesa dos Cofres da Fazenda Real das Ilhas, Ilha do Príncipe, 29 mar. 1813; cx. 49, doc. 8, Mapas da Receita e Despesa dos Cofres da Fazenda Real destas Ilhas, Ilha do Príncipe; cx. 50, doc. 4, Mapas da Receita e Despesa dos Cofres da Fazenda Real destas Ilhas, Ilha do Príncipe, 13 maio 1815; e cx. 50, doc. 30, Mapas da Receita e Despesa dos Cofres da Fazenda Real destas Ilhas, Ilha do Príncipe, 2 out. 1816; cx. 50, doc. 30, Mapas da Receita e Despesa dos Cofres da Fazenda Real destas Ilhas, Ilha do Príncipe, 2 out. 1816; cx. 51, doc. 15, Mapas da Receita e Despesa dos Cofres da Fazenda Real destas Ilhas, Ilha de São Tomé, 26 mar. 1817; e cx. 51, doc. 37, Mapas da Receita e Despesa dos Cofres da Fazenda Real destas Ilhas, Ilha do Príncipe, 20 jul. 1818.

18 A informação sobre a isenção consta no Ofício de $1^{\circ}$ de abril de 1809 em resposta ao Aviso Real de maio de 1807. Tal referência é generalista, ou seja, a dispensa foi concedida a todas as embarcações. Cito: "isenção Concedida por S. A. R a todos os Mestres dos Navios do Brazil”. AHU CU STP, cx. 43, doc. 20, Ofício de $1^{\circ}$ de abril de 1809 em resposta ao Aviso Real de maio de 1807, Ilha do Príncipe, 1 abr. 1809. É do conhecimento que, durante o período de 1710 a 1800, os navios negreiros da Bahia, tanto na ida quanto na volta da Costa da Mina, tinham de escalar em São Tomé pagando impostos. Seibert, “Colonialismo”, p. 108. 
“considerável” e o que "traria a inteira e absoluta e imediata ruína delas [São Tomé e Príncipe]”. 19

Os motivos apresentados foram cinco, mas, possivelmente, o principal foi a falta de gêneros de primeira necessidade que as embarcações utilizavam para o resgate de escravizados.

$1^{\circ}$ em não ter o cofre real outras rendas, senão os direitos que estes navios pagavam para satisfazer aos filhos da folha; $2^{\circ}$ na falta de venda dos mantimentos que tais navios se prestavam; $3^{\circ}$ em não haver mais Europeus e Brasileiros para casarem com as mulheres brancas e pardas; $4^{\circ}$ em acabar de uma vez, e não tornar a aparecer mais nenhum grão de Ouro para as compras dos gêneros comerciais e $5^{\circ}$ finalmente na falta de gêneros de primeira necessidade que estes navios importavam para o resgate de escravos. ${ }^{20}$

No entanto, as alegações do governador não foram consideradas. Posteriormente, foram ordenadas providências para promover os ramos do comércio e da agricultura, que, segundo informações repassadas à Coroa, se encontravam em forte queda.

Contra-argumentando, o governador apresentou a situação da possessão até meados de 1808. Luís Joaquim Lisboa (1805-1817) ofereceu vários mapas sobre a entrada de embarcações nos portos da possessão desde a época do governo de João Baptista da Silva, ou seja, de agosto de 1799 até outubro de 1808. Vejamos os dados relativos ao comércio de escravizados nas tabelas a seguir:

19 AHU CU STP, cx. 43, doc. 20, Ofício de 1 de abril de 1809.

20 Importante salientar que ao citar "falta de gêneros", referia-se a alimentos e outros gêneros de primeira necessidade. AHU CU STP, cx. 43, doc. 20, Ofício de 1 de abril de 1809. 
Tabela 1

Comércio de escravizados em São Tomé entre 4 de agosto de 1799 e 13 de setembro de 1808

\begin{tabular}{|c|c|c|c|c|c|c|}
\hline & & & Escr & avos & Direitos & Total geral \\
\hline & & aportadas & Import. & Export. & importados & plfândega \\
\hline & $\begin{array}{c}\text { João Baptista } \\
\text { da Silva } \\
(1799-1802)\end{array}$ & 13 & 666 & - & 2:331\$000 & $2: 337 \$ 250$ \\
\hline $\begin{array}{l}\text { embarcações } \\
\text { oriundas } \\
\text { dos portos do }\end{array}$ & $\begin{array}{c}\text { Gabriel } \\
\text { A. Franco } \\
\text { de Castro } \\
(1802-1805)\end{array}$ & 7 & 304 & - & 1:064\$000 & $1: 082 \$ 643$ \\
\hline & $\begin{array}{l}\text { Luís Joaquim } \\
\text { Lisboa } \\
\text { (1805-1817) }\end{array}$ & 11 & 222 & - & $777 \$ 000$ & $847 \$ 274$ \\
\hline & $\begin{array}{c}\text { João Baptista } \\
\text { da Silva } \\
(1799-1802)\end{array}$ & 30 & 2.147 & - & 7:979\$660 & 7:979\$660 \\
\hline $\begin{array}{l}\text { portuguesas } \\
\text { oriundas da } \\
\text { Europa, da }\end{array}$ & $\begin{array}{c}\text { Gabriel A. } \\
\text { Franco de Castro } \\
\text { (1802-1805) }\end{array}$ & 51 & 2.207 & 1.894 & $11: 405 \$ 270$ & $12: 036 \$ 425$ \\
\hline Américas & $\begin{array}{l}\text { Luís Joaquim } \\
\text { Lisboa } \\
\text { (1805-1817) }\end{array}$ & 52 & 2.786 & 2.888 & $12: 507 \$ 448$ & $13: 375 \$ 801$ \\
\hline Totais & & 164 & 8.332 & 4.782 & $36: 064 \$ 378$ & $37: 659 \$ 053$ \\
\hline
\end{tabular}

Fonte: AHU CU STP, cx. 43, doc. 20, Ofício de 1 de abril de 1809. ${ }^{21}$

21 Apesar do tráfico português na Costa da Mina ter apresentado queda de $42 \%$ durante o recorte temporal de 1776 a 1800 (Neves, S. Tomé e Príncipe na segunda metade do séc. XVIII, p. 119), a partir da segunda metade da década de 1810, o comércio de escravizados diminuiria ainda mais após a proibição inglesa. 
Tabela 2

Comércio de escravizados em Príncipe entre 4 de agosto de 1799 e 29 de outubro de 1808

\begin{tabular}{|c|c|c|c|c|c|c|}
\hline & & Quantidade & Esc & avos & Direitos & Total geral \\
\hline (período & e governo) & embarcaçôes & Import & Fynort & os escravos & pela \\
\hline & $\begin{array}{c}\text { João Baptista } \\
\text { da Silva } \\
\text { (1799-1802) }\end{array}$ & 15 & 1.015 & - & $3: 468 \$ 500$ & $3: 493 \$ 550$ \\
\hline $\begin{array}{l}\text { embarcações } \\
\text { oriundas dos } \\
\text { portos do } \\
\text { Gabão (até }\end{array}$ & $\begin{array}{c}\text { Gabriel } \\
\text { A. Franco } \\
\text { de Castro } \\
(1802-1805)\end{array}$ & 18 & 958 & - & $3: 353 \$ 000$ & $3: 390 \$ 650$ \\
\hline 1808) & $\begin{array}{l}\text { Luís Joaquim } \\
\text { Lisboa } \\
\text { (1805-1817) }\end{array}$ & 39 & 1.464 & - & $5: 111 \$ 000$ & $5: 302 \$ 007$ \\
\hline Fntr 2 & $\begin{array}{c}\text { João Baptista } \\
\text { da Silva } \\
(1799-1802)\end{array}$ & 29 & 4.285 & - & $14: 997 \$ 500$ & $15: 603 \$ 873$ \\
\hline $\begin{array}{l}\text { portuguesas } \\
\text { oriundas da } \\
\text { Europa, da }\end{array}$ & $\begin{array}{c}\text { Gabriel A. } \\
\text { Franco de Castro } \\
(1802-1805)\end{array}$ & 39 & 3.605 & - & $12: 617 \$ 500$ & $14: 162 \$ 919$ \\
\hline 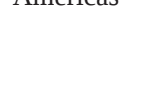 & $\begin{array}{l}\text { Luís Joaquim } \\
\text { Lisboa } \\
\text { (1805-1817) }\end{array}$ & 76 & 4.290 & - & $15: 015 \$ 000$ & $17: 285 \$ 431$ \\
\hline Totais & & 216 & 15.617 & - & $54: 562 \$ 500$ & $59: 238 \$ 430$ \\
\hline
\end{tabular}

Fonte: AHU CU STP, cx. 43, doc. 20, Ofício de 1 de abril de 1809.

A partir da Tabela 1, observa-se que no período São Tomé importou 8.332 escravizados e exportou 4.782, o que possibilita interpretar que $43 \%$ tiveram como destino a própria ilha, ou seja, foram utilizados na agricultura local. É evidente que com a diminuição do número de 
embarcações inglesas a ilha sofreu não só o impacto negativo na exportação de escravizados, mas na oferta e reposição da mão de obra de sua agricultura. Esse fato foi uma das questões apresentadas pelo governador em sua resposta sobre a "decadência” da possessão. Contudo, após analisar os dados encaminhados pelo governador Luís Joaquim Lisboa, percebe-se uma retomada do comércio de escravizados. Ocorre que, desde a segunda metade do século XVIII, a Costa da Mina já não contava com uma forte presença de traficantes portugueses, conforme observou Carlos Agostinho das Neves. ${ }^{22} \mathrm{O}$ que buscava o governador com a apresentação das informações sobre a importação e exportação de escravos, então, era mostrar que, mesmo com a decadência, o seu governo estava comercializando mais escravos em comparação aos dois últimos governadores; logo, Luís Joaquim Lisboa empenhava-se pela reposição da mão de obra da agricultura.

Já a situação da ilha do Príncipe nessa mesma época, de acordo com os dados encontrados nos mapas da alfândega, era pior. Se em São Tomé um pouco menos da metade dos escravizados importados ficaram na ilha, em Príncipe a totalidade importada era absorvida pelas atividades locais (Tabela 2). ${ }^{23}$ Ponderamos a impossibilidade da totalidade de escravizados importados não se destinar à própria ilha do Príncipe, no entanto, a documentação analisada não fornece dados sobre a exportação deles a partir da ilha. Salientamos, ainda, que as informações são sobre as importações e exportações de escravizados, isto é, não se referem ao quantitativo de escravos existentes no arquipélago. ${ }^{24}$

Se o abastecimento da mão de obra dependia, em grande parte, das mercadorias adquiridas nas negociações principalmente com as embarcações inglesas, americanas e brasileiras, a proibição do tráfico

22 Neves, S. Tomé e Príncipe na segunda metade do séc. XVIII, p. 119.

23 A ilha de Príncipe durante a segunda metade do século XVIII e nos anos iniciais do século XIX era mais aproveitada pela agricultura. Ver mais em: Neves, S. Tomé e Príncipe na segunda metade do séc. XVIII, pp. 84-85.

24 Ao somarmos as importações, encontramos o total de 23.949 escravizados para o período entre agosto de 1799 e outubro de 1808. 
pela Inglaterra e a isenção concedida aos navios do Brasil impactaram negativamente São Tomé e Príncipe. Para além desses fatos, observa-se ainda a importância da comercialização de escravizados para a arrecadação das alfândegas. O total dos direitos recolhidos nas duas ilhas foi de 96:897\$483 réis e o valor dos direitos reais sobre a importação de escravizados alcançou 90:626\$878 réis. Isto é, 93,52\% de toda a arrecadação, o que demonstra a exploração e o desenvolvimento à base do tráfico e do sistema escravista.

Quanto ao valor do escravizado em São Tomé e Príncipe, encontramos a cotação de $3 \$ 500$ réis. Ao compararmos com Angola, que tinha como principal ramo comercial a exportação de africanos, encontramos grande diferença. A alfândega de Luanda registrava o valor de $8 \$ 700$ réis por “cabeça” e $4 \$ 300$ réis por "cria de pé”. ${ }^{25}$ Diante da importância econômica do tráfico para o desenvolvimento da possessão, quais foram as sugestões para a saída e superação da nova conjuntura a partir de 1808 ?

\section{O café como opção para a recuperação econômica}

Uma primeira proposta foi apresentada pelo governador Luís Joaquim Lisboa que apostava na lavoura de café, tendo em vista a qualidade e o interesse inglês e americano pelo grão produzido. Mas haveria outra?

Outra possibilidade era tirar proveito dos portos que antes eram de domínio dos ingleses, como o porto de Calabar no Golfo da Guiné. Nesse sentido, foi apresentada a ação de Manoel Marques Camacho, morador da ilha de Príncipe, que comprou "duzentos e dezoito escravos" em Calabar. A citação da compra realizada visava incentivar os "negociantes dos

25 Cria de pé era a denominação dada às crianças escravizadas que já conseguiam andar. Os dados referentes a Angola são para o período de 1812 a 1817. Manuel dos Anjos da Silva Rebelo, Relações entre Angola e Brasil (1808-1830), Lisboa: Agência Geral do Ultramar, 1970, pp. 82-87. 
Portos do Brasil a frequentarem o Comércio daquele Porto donde sai maior número de Escravos que de todo o Continente de Angola e Benguela”. ${ }^{26}$

Contudo, ao menos inicialmente, essas propostas não foram consideradas como esperava o governador. O Brasil manteve Angola como principal fornecedora de escravizados, enquanto São Tomé e Príncipe continuava a enfrentar as perdas advindas da proibição inglesa do tráfico e da isenção concedida às embarcações do Brasil, buscando superá-las com a lavoura do café, que dependia do interesse externo para alcançar maior desenvolvimento.

Percebe-se, ainda, que a queda econômica em São Tomé e Príncipe não era relacionada à ausência produtiva. Como não havia mais a mesma presença de embarcações estrangeiras, a produção era perdida por não ter a quem vender. De acordo com o governador, "há tanto mantimento, que os lavradores perdem todas as suas colheitas, o que por nenhum modo sucedia se continuasse o referido Comércio dos Escravos”. E continuava: "apesar de haver [...] tais produções [farinha de mandioca, milho, feijão, inhame, azeite de palma, coco e café] da Agricultura, estes mesmos se arruínam totalmente em poder dos Lavradores em prejuízo deles e mesmos dos dízimos Reais”. ${ }^{27} \mathrm{O}$ café, em razão da demanda do mercado, seria atrativo para gerar maior presença de embarcações estrangeiras na possessão, dinamizando a agricultura.

Ainda sobre a escassez comercial após o fim do tráfico imposto pelos ingleses e a isenção dada às embarcações do Brasil, salientava-se que a total falta de comércio não era oriunda somente da exiguidade de navios estrangeiros, mas também por "não virem a esta ilha embarcações nacionais comprar produções”. A possessão quase não exportava para a

26 AHU CU STP, cx. 43, doc. 28, Ofício.

27 Segundo o Ofício Resposta ao Real Aviso de 16 de março de 1808. AHU CU STP, cx. 43, doc. 20, Ofício de $1^{\circ}$ de abril de 1809. 
metrópole em razão da alta taxa ${ }^{28}$ de entrada no reino, e também por não haver uma efetiva comunicação. ${ }^{29}$

O café em São Tomé e Príncipe atenuaria, de uma só vez, dois problemas. Ao negociar sua produção, as ilhas atrairiam maior interesse de embarcações estrangeiras, que, por sua vez, supririam, em parte, a ausência de barganha com o reino. A cultura cafeeira foi introduzida no arquipélago em 1789 pelo capitão-mor João Baptista da Silva que trouxe sementes e mudas do Brasil, ${ }^{30}$ mas sofreu resistência do então governador João Resende Tavares Leote (1788-1797) por “ser rentável a muito longo prazo". ${ }^{31}$ Esse ponto parece ter sido o principal problema ou barreira para a expansão da cultura - em média o café apresentava o primeiro retorno só após quatro anos -, além da existência do comércio de escravizados. Outro ponto que parece ter gerado discussão foi a dependência do trabalho escravizado, que, segundo Tenreiro, gerou "perturbações sociais violentas, que giram quase sempre em torno do problema da mão de obra”. ${ }^{22}$

28 A cobrança sobre a entrada na metrópole de mercadorias oriundas das possessões em África era de $30 \%$, alíquota reduzida somente no ano de 1829 por meio do Alvará de 14 de dezembro de 1829. Biblioteca da Assembleia da República de Portugal (BAR), Lisboa, Legislação Régia, Livro 1829, $2^{\circ}$ Sem., n. 15, p. 30, Lisboa, 14 dez. 1829 ש.

29 Augusto Nascimento, "S. Tomé na segunda metade de Oitocentos: a construção da sociedade colonial”, Dissertação (Mestrado em História), Faculdade de Ciências Sociais e Humanas, Universidade Nova de Lisboa, Lisboa, 1992, p. 23. Importa salientar a ligação mais ativa de São Tomé e Príncipe com a Bahia do que com a metrópole, cuja correlação passava pela subordinação da Diocese e do próprio Tribunal. São Tomé e Príncipe ainda recebeu da Alfândega da Bahia, a título de direitos sobre os escravos exportados, valores anuais de 9:000\$000 réis, segundo Augusto Nascimento. Essa ajuda ocorreu até o ano de 1824 sob a denominação de "Dinheiro vindo do Real Erário e Junta Real Fazenda da cidade da Bahia”. Augusto Nascimento, “São Tomé e Príncipe” in Valentim Alexandre e Jill Dias, Nova História da expansão portuguesa: o império africano (1825-1890) (Lisboa: Estampa, 1998), p. 272. Observamos que esse montante foi inconstante. Por exemplo, no ano de 1813, o repasse foi de 246\$324 réis, já em 1814 chegou a 3:000\$000 réis. AHU CU STP, cx. 49, doc. 8, Mapas da Receita e Despesa dos Cofres da Fazenda Real destas Ilhas, Ilha do Príncipe; AHU CU STP, cx. 50, doc. 4, Mapas da Receita e Despesa dos Cofres da Fazenda Real destas Ilhas, Ilha do Príncipe, 13 maio 1815.

30 José E. Mendes Ferrão, O café: a bebida negra dos sonhos claros, Lisboa: Chaves Ferreira, 2009, p. 31.

31 Neves, S. Tomé e Príncipe na segunda metade do séc. XVIII, p. 82.

32 Tenreiro, A ilha de S. Tomé, p. 78. 
Mas, para Augusto Nascimento, a produção ou a prosperidade trazidas pelo café em São Tomé e Príncipe ocorreram em razão “do acesso à mão de obra e o menor custo das terras". ${ }^{33}$ Todavia, conforme salientado pelo próprio Nascimento, o impulso cafeeiro ocorreu na "sequência da revogação em 1808 dos navios negreiros a operar no golfo da Guiné”, 34 ponto que conflui com a argumentação de Eyzaguirre sobre o estabelecimento de plantações pelos comerciantes de escravizados por não poder reinvestir no tráfico. ${ }^{35}$

Nessa mesma época, o Golfo da Guiné vivenciava um período de estímulo à agricultura. Antes da proibição do tráfico pela Inglaterra, entre os anos de 1802 e 1803, a Dinamarca havia proibido o comércio de escravizados na Costa do Ouro, onde desde 1796 passou a incentivar a agricultura para estabelecer uma colônia com renda alternativa ao comércio de africanos. ${ }^{36}$ Mas essa "alternativa” esbarrava na questão econômica de ser mais lucrativo exportar escravizados do que utilizá-los em África. ${ }^{37} \mathrm{Um}$ segundo ponto era as correntes marítimas do Atlântico, que favoreciam as navegações para as Américas, ou seja, era mais fácil chegar ao novo continente do que à Europa a partir de África. ${ }^{38}$

Somando todos esses fatores à "impossibilidade" tributária de exportar para o reino, São Tomé e Príncipe tinha no comércio de escravizados sua principal via de escoamento da produção agrícola. Em razão

33 Nascimento, “S. Tomé na segunda metade de Oitocentos”, p. 30.

34 Nascimento, "S. Tomé na segunda metade de Oitocentos”, p. 31.

35 Pablo B. Eyzaguirre, "Small Farmers and Estates in São Tomé, West Africa”, Tese (Doutorado), Yale University, New Heaven, 1986.

36 Ray A. Kea, "Plantations and labour in the south-east Gold Coast from the late eighteenth to the mid nineteenth century" in Robin Law (ed.), From Slave Trade to 'Legitimate' commerce. The commercial transition in nineteenth century West Africa (Cambridge: Cambridge University Press, 1995), p. 78 e p. 123. Outra barreira que dificultou o crescimento da agricultura foi a alta taxa de mortalidade de europeus em África.

37 Robin Law, “'There’s Nothing Grows in the West Indies but Will Grow Here’: Dutch and English Projects of Plantation Agriculture on the Gold Coast, 1650s-1780s” in Robin Law, Suzanne Schwarz e Silke Strickrodt (eds.), Commercial Agriculture, the Slave Trade and Slavery in Atlantic Africa (Woodbridge: James Currey, 2014), p. 134.

38 Law, “'There’s Nothing Grows in the West Indies but Will Grow Here’”, p. 135. 
da proibição inglesa e da utilização de escravizados nas roças, em pouco tempo o café começou a despertar o interesse estrangeiro. Segundo Carlos Agostinho das Neves, desde 1795 os ingleses de Serra Leoa buscavam adquirir plantas de café de São Tomé. ${ }^{39}$

O comércio com os estrangeiros foi essencial para o desenvolvimento da agricultura no início do século XIX, em especial para o café. Utilizado como moeda de troca nas barganhas com as embarcações estrangeiras, o grão terminava por possibilitar o acesso a produtos necessitados pelo arquipélago. Contudo, o café tornou-se uma condição de importação crescente de escravizados; ${ }^{40}$ e, embora sofresse com a concorrência da reexportação dos cativos e, posteriormente, com a proibição inglesa, a cultura cafeeira se manteve em crescimento durante toda a primeira metade do Oitocentos. A partir de 1825, o mapa da receita da real Fazenda de São Tomé passou, numa coluna específica, a fornecer dados sobre a recolha de direitos sobre a comercialização do café, denominada "Do Café exportado em Navios Nacionais e Estrangeiros”. ${ }^{41}$

Possivelmente, após sua introdução, a cultura e, por conseguinte, os "brancos da terra” beneficiaram-se não só do comércio com os navios negreiros ou das ações de comerciantes, ${ }^{42}$ mas principalmente de um mercado com maior demanda que oferta após a revolução de São Domingos. $^{43}$

39 Neves, S. Tomé e Príncipe na segunda metade do séc. XVIII, p. 89.

40 Nascimento, “S. Tomé na segunda metade de Oitocentos”, p. 32.

41 AHU CU STP, cx. 56, doc. 72, Mapa da receita da real Fazenda da ilha de São Tomé ano de 1825, Ilha do Príncipe, 1825.

42 Augusto Nascimento pontua que a cultura foi animada por comerciantes. Augusto Nascimento, Poderes e quotidiano nas roças de S. Tomé e Príncipe, Lousã: Lousanense, 2002, p. 56 n. 8.

43 São Domingos, aqui, não se refere à Ilha de São Domingos, que atualmente se divide em dois países: Haiti e República Dominicana. São Domingos a que nos referimos trata-se da parte francesa da ilha, Saint-Domingue, que no início do século XIX se tornaria o independente Haiti, maior produtor de café durante o período colonial. 


\section{Lavradores(as) proprietários(as) de escravizados(as)}

É evidente que alguns envolvidos no comércio de escravizados também se apresentavam como lavradores no arquipélago. ${ }^{44}$ Assim, cruzamos os nomes de moradores proprietários de embarcações envolvidas no resgate de escravizados com a listagem dos principais lavradores da possessão e o consequente plantel de escravos. Os dados recolhidos são relativos aos mapas elaborados no ano de 1808. Na relação referente à ilha de São Tomé, encontramos três são-tomenses: Thomé Ferreira Neto, Silverio Jozé de Mattos e Manoel Pires do Sacramento, ${ }^{45}$ dos quais dois, Thomé Ferreira e Silverio Jozé, constavam na relação dos principais lavradores da ilha. Insta salientarmos que a elaboração da relação dos lavradores pautou-se sobre o número de escravizados e não sobre os produtos cultivados; assim, foram listados 26 lavradores com o total de 1.394 escravizados (Tabela 3). ${ }^{46}$

No que concerne à ilha de Príncipe, havia sete moradores proprietários de embarcações envolvidas no resgate de escravizados, dos quais quatro figuram entre os principais lavradores, a saber: António Henriques Nogueira, Jozé Xavier Gonzaga de Sá, Brás Luis Borges de Mesquita e Jozé Ribeiro [...] Gastão. Numa relação de 35 lavradores foram contabilizados 2.477 escravizados (Tabela 3).

44 De acordo com Eyzaguirre foram os comerciantes de escravizados, após acumular capital, que estabeleceram plantações. Eyzaguirre, "Small Farmers”.

45 AHU CU STP, cx. 44, doc. 15, Mapas das Embarcações pertencentes aos moradores de São Tomé e Príncipe - Relações dos Principais lavradores da ilha de São Tomé e Príncipe - Declaração dos escravos que empregão na sua lavoura, 30 jun. 1810.

46 O maior proprietário, Leandro Jozé da Costa, tinha 306 escravizados, dos quais 138 eram mulheres. AHU CU STP, cx. 44, doc. 15, Mapas das Embarcações pertencentes aos moradores. 
Tabela 3

Lavradores(as) e escravos(as) de São Tomé e Príncipe em 1808

\begin{tabular}{c|c|c|c|c|c}
\hline & $\begin{array}{c}\text { Totais de } \\
\text { lavradores }\end{array}$ & $\begin{array}{c}\text { Totais de } \\
\text { lavradoras }\end{array}$ & $\begin{array}{c}\text { Escravos } \\
\text { pertencentes às } \\
\text { lavradoras }\end{array}$ & Escravas & $\begin{array}{c}\text { Totais de } \\
\text { escravos }\end{array}$ \\
\hline S. Tomé & 26 & 6 & 227 & 684 & 1.394 \\
\hline Príncipe & 35 & 8 & 620 & 1.272 & 2.477 \\
\hline
\end{tabular}

Fonte: AHU CU STP, cx. 44, doc. 15, Mapas das Embarcações pertencentes aos moradores.

Chamou-nos a atenção o número de mulheres lavradoras-proprietárias e a quantidade de escravas. Em São Tomé as lavradoras Thomazia de Brito Porto, D. Thereza Maria de Jezus, D. Margarida Ferreira, Izabel Vas, D. Maria do Nascimento e D. Maria Fernandes Gabriel eram proprietárias de 227 cativos, dos quais 124 eram escravas. Por sua vez, a ilha de Príncipe apresentou oito proprietárias, a saber: Antonia Leocadio, D. Roza Maria, D. Anna Gomes Salvada, D. Anna Joaquina, D. Maria Pinta, D. Jozefa Maria, D. Maria dos Santos e D. Anna Mendes, “donas” de 620 escravizados, dos quais 341 eram escravas. ${ }^{47}$

Se em relação aos proprietários homens torna-se um pouco complicado informar a origem, para os agricultores responsáveis pela cultivação do café é mais fácil afirmar que a maioria era composta pelo grupo de "brancos da terra". De acordo com Augusto Nascimento, foi a "indigenização do cultivo do café” o principal fator para o sucesso das plantações no arquipélago; ${ }^{48}$ e continua o historiador: “a cultura de exportação - então a do café - não foi imediatamente desenvolvida em grandes propriedades, antes esteve a cargo de pequenos proprietários”. ${ }^{49}$

Em relação às mulheres proprietárias, a explicação dava-se em razão da prática de casamento das "filhas da ilha” com europeus, em

47 AHU CU STP, cx. 44, doc. 15, Mapas das Embarcações pertencentes aos moradores.

48 Nascimento, Poderes e quotidiano, p. 56.

49 Augusto Nascimento, "S. Tomé e Príncipe no século XIX: um esboço de interpretação das mudanças sócias” in Valentim Alexandre, O império Africano (séculos XIX e XX), $3^{\mathrm{a}}$ ed. (Lisboa: Colibri, 2013), p. 97. 
especial com aqueles que tinham ligações com o alto funcionalismo régio. ${ }^{50}$ Assegurados o prestígio social da "filha” e a riqueza ao marido, em caso de falecimento do homem ou pela obtenção de herança, a mulher tornava-se "cabeça do casal". ${ }^{51}$ Assim, em muitos casos, passava a controlar as atividades comerciais. Possivelmente, essa é a explicação para o expressivo número de lavradoras-proprietárias encontradas em 1808, para além do fato de a presença de mulheres proprietárias ser uma referência na história do arquipélago. ${ }^{52}$

Um segundo aspecto observado é o quantitativo de mulheres escravizadas sob propriedade dos lavradores e lavradoras de São Tomé e Príncipe. Nesse sentido, concordamos com a argumentação de Daniel B. Domingues de que a proibição inglesa fez aumentar a procura por escravizadas do sexo feminino, ${ }^{53}$ mas também há outros dois pontos que podem contribuir para a explicação do alto contingente de mulheres escravizadas. O primeiro é uma maior valorização do trabalho feminino pelos africanos; o segundo é a imprescindibilidade do trabalho da mulher para a agricultura na África Centro-ocidental. ${ }^{54}$

Provavelmente, a mão de obra feminina foi de grande importância para o avanço da cultura cafeeira em São Tomé e Príncipe num período de baixa transação comercial em razão da parca presença de navios estrangeiros. O café manteve o interesse estrangeiro, e essa presença estimulou a cultura que se destacou ao longo de toda a metade inicial do século XIX. Afora a importância do trabalho feminino para a roça do café, importa salientarmos esse aspecto que diferenciava o trabalho no arquipélago daquele empregado nas lavouras do Brasil, majoritariamente masculino. ${ }^{55}$

50 Caldeira, “Mestiçagem”, p. 58.

51 Caldeira, “Mestiçagem”, p. 65.

52 Ver mais em: Caldeira, "Mestiçagem”.

53 Daniel B. Domingues da Silva, Atlantic Slave Trade in the Century of Abolition, 1780-1867, Cambridge: Cambridge: University Press, 2017, p. 100.

54 Silva, Atlantic Slave Trade, p. 102 e p. 109.

55 No ano de 1840 foi aberto o inventário de um dos maiores proprietários de terras, escravos e produtor de café do Vale do Paraíba fluminense: Manoel Francisco Xavier apresentou 446 escravos, dos quais apenas 15,7\% correspondiam a mulheres, ou 
Dois anos depois, em 1810, foi apresentada uma nova lista com treze embarcações e seus respectivos proprietários. Novamente foi possível observar a atuação de comerciantes de escravizados na agricultura do arquipélago. Em São Tomé, Thomé Ferreira Neto e Silvério Jozé de Mattos mantinham a posição entre os principais lavradores da ilha; ${ }^{56}$ contudo, mesmo tratando-se de comerciantes de africanos, não apresentavam grande plantel de escravizados. Thomé F. Neto possuía treze homens e dezoito mulheres, já Silvério Jozé, oito homens e dezoito mulheres. ${ }^{57}$

Na ilha de Príncipe os donos de embarcações com destaque entre os grandes lavradores se mantiveram: Antonio Henriques Nogueira, Jozé Xavier Gonzaga de Sá, Brás L. Borges de Mesquita e Jozé Ribeiro [...] Gastão, que apresentavam grande plantel de escravizados, exceto Brás L. Borges de Mesquita, com apenas dezessete homens e 21 mulheres.

Jozé Xavier Gonzaga de Sá possuía 138 homens e 145 mulheres, Antonio H. Nogueira apresentava o quantitativo de 71 homens e 56 mulheres e, por fim, Jozé Ribeiro [...] Gastão com 75 homens e 51 mulheres. ${ }^{58}$ Ao somar apenas o quantitativo de escravizados desses negociantes-lavradores encontramos o total de 631 escravizados, dos quais 309 eram mulheres (48,96\%).

seja, 70 escravas. Centro de Documentação Histórica (CDH), Universidade Severino Sombra (USS), Vassouras, Inventário Post Mortem de 1840 de Manuel Francisco Xavier. O centro de documentação foi encerrado. Cópia do documento foi cedida, gentilmente, por Adelci dos Santos.

56 AHU CU STP, cx. 44, doc. 15, Mapas das Embarcações pertencentes aos moradores.

57 AHU CU STP, cx. 44, doc. 15, Mapas das Embarcações pertencentes aos moradores.

58 AHU CU STP, cx. 44, doc. 15, Mapas das Embarcações pertencentes aos moradores. 


\section{A (des)conexão da economia de São Tomé e Príncipe com Portugal}

A produção cafeeira do arquipélago sofreu consequências em razão da proibição inglesa com a falta de comercialização do produto ou a presença de embarcações estrangeiras; mas, aparentemente, trata-se de algo pontual, um desdobramento imediato da interdição. De qualquer forma, o governador Luís Joaquim Lisboa comunicou a ausência de embarcações e o impacto na comercialização do café produzido.

Decadência na falta da compra do Café, que as embarcações Americanas a [...] vinham a estas ilhas permutar por Ouro e gêneros comerciáveis na Costa de África, e de que resultavam grandes interesses ao Cofre Real e aos Agricultores. [...] por causa da extinção do Comércio dos Escravos, por ser certo que o grande número de Embarcações Americanas que aportavam a estas ilhas vinham directamente negociar aquelas Fortalezas e com o Ouro que lá recebiam e com os gêneros que lhes restavam que faziam Compra do Café produzido nestas colônias [...]..$^{59}$

Ainda sobre o café, o governador declarou ser ainda “de pouca vantagem por falta igualmente de exportação Nacional, e senão conhecia alguma utilidade até o presente senão fossem alguns Ingleses, Americanos dos Estados Unidos por meio tão bem de trocas, o terem exportado alguns anos para os seus interesses". ${ }^{60}$

O envio de café para Lisboa estava inviabilizado pela morosidade das comunicações e pelos elevados direitos reais; ${ }^{61}$ assim, interpretamos a falta de exportação nacional como ausência de comércio com o reino. Problema comum às possessões do Atlântico, por exemplo, Cabo Verde em 1803, por meio das instruções enviadas ao novo governador, já “sofria”

59 AHU CU STP, cx. 43, doc. 20, Ofício de $1^{\circ}$ de abril de 1809

60 AHU CU STP, cx. 43, doc. 20, Ofício de $1^{\circ}$ de abril de 1809

61 Nascimento, “S. Tomé na segunda metade de Oitocentos”, p. 23. 
a cobrança para estimular a navegação direta com o reino, no entanto, o estímulo ficava a cargo dos comerciantes. ${ }^{62}$

Segundo Augusto Nascimento, a conexão da economia da ilha de São Tomé com a do reino dependia da oferta de café, dos encargos alfandegários e dos fretes. ${ }^{63}$ Todavia, mesmo com todas essas questões, a cultura do grão se expandia e também já apresentava algumas consequências negativas sobre outras culturas na ilha de Príncipe.

Esta abundância por de grãos tem sido sempre em diminuição até o presente tempo em que o Alqueire de farinha tem chegado a dez tostões e a doze e, às vezes, nem por este preço se achava a que se precisava de que tem resultado fugirem os navios desta ilha, e irem à ilha de São Tomé e [...] outros fazerem as suas viagens em direto. Esta decadência deve necessariamente ter algumas causas, que a produzam e a primeira parece ser ou é a mesma cultura do Café, pois não há novos braços que nela se empreguem deve forçosamente enfraquecer-se nos outros artigos. ${ }^{64}$

Contudo, diante do contexto antitráfico inglês que, de acordo com Augusto Nascimento, ocasionou aos "ilhéus [...] maiores dificuldades na continuação do seu envolvimento com o tráfico”, “a possibilidade de exportação de café aparecia como um substituto para os [comerciantes] como empreendimentos económicos que, até então, tinha sustentado os ilhéus”. ${ }^{65}$

Devido ao embaraço na importação de escravizados para a agricultura e à guerra francesa na Europa, o comércio decaiu e as embarcações portuguesas "apenas aparecia[m] por estas ilhas [...] por efeito de alguma grande urgente necessidade, pois antes se quererem pôr no risco

62 Instruções da Secretaria de Estado dos Negócios da Marinha e Domínios Ultramarinos antes da tomada de posse do novo governador de Cabo Verde, D. António Coutinho de Lencastre, presente em Daniel A. Pereira, Novos subsídios para a história de Cabo Verde (século XIX), Lisboa: Rosa de Porcelana, 2016, pp. 231-232. Documento totalmente transcrito.

63 Nascimento, “S. Tomé na segunda metade de Oitocentos”, p. 23.

64 AHU CU STP, cx. 43, doc. 20, Ofício de $1^{\circ}$ de abril de 1809.

65 Nascimento, “S. Tomé e Príncipe no século XIX”, p. 99. 
de perderem as suas nações, por fome, e sede, do que virem a alguma destas ilhas”. O desdobramento pelo abandono da relação comercial com as possessões era a inutilidade "da maior parte dos artigos da agricultura por falta de consumo". ${ }^{66}$

Diante desse contexto comercial confuso e de impacto negativo sobre a produção de outros gêneros, as ilhas de São Tomé e Príncipe não tinham, segundo a opinião do governador Luís Joaquim Lisboa, “outro socorro mais que agricultura do café que sua qualidade chama a estas ilhas os Ingleses, Americanos que não carregam mais porque não há”, ${ }^{67}$

Mesmo tratando-se de uma cultura recomendada pelo governo central desde a segunda metade do século XVIII, a produção de café em São Tomé e Príncipe, ao menos na década inicial do século XIX, parece-nos ter sido fruto da ação do governador da possessão que enxergou no grão a possibilidade de obter uma maior troca comercial, e, por conseguinte, o abastecimento de gêneros necessitados pelos habitantes.

Se a proibição inglesa do tráfico, com o passar dos anos, fez diminuir a presença de navios negreiros, o café manteve, mesmo que em número inferior, o interesse de estrangeiros pelo arquipélago em razão de sua qualidade ${ }^{68}$ e da existência de um mercado ansioso pelo grão após a queda na oferta depois da revolução de São Domingos.

Ainda que negociado a preço inferior, apesar da qualidade superior, ${ }^{69}$ o café das ilhas durante a primeira metade do Oitocentos foi cotado, em média, a 2\$300 réis, enquanto em Luanda o valor alcançava $4 \$ 800$ réis a arroba; ${ }^{70}$ de qualquer modo, o grão era apontado como uma

66 AHU CU STP, cx. 43, doc. 20, Ofício de $1^{\circ}$ de abril de 1809.

67 AHU CU STP, cx. 43, doc. 20, Ofício de $1^{\circ}$ de abril de 1809.

68 Augusto Nascimento não considera o café como de alta qualidade, de acordo com o historiador, o baixo atributo devia-se à venda garantida do grão, à carência monetária e à transformação da terra em capital, ver Nascimento, "S. Tomé e Príncipe no século XIX”, pp. 56-57.

69 O café de São Tomé e Príncipe era considerado equiparável ao do Brasil e superior ao de Angola, que era tido como amargo.

70 Durante a década de 1840, o café em S. Tomé e Príncipe foi cotado a $2 \$ 000$ réis. AHU, Secretaria de Estado da Marinha e Ultramar, Direção-Geral do Ultramar (SEMU-DGU), São Tomé e Príncipe, nv. 486, pt. 3, Mapa dos Gêneros de produção 
cultura que "poderia enriquecer os seus habitantes e aumentar as rendas Reais”, mas não era possível a São Tomé e Príncipe “adiantar sem a ajuda de fora”. ${ }^{71} \mathrm{O}$ socorro externo mencionado pelo governador Luís Joaquim Lisboa referia-se ao interesse e à presença de embarcações estrangeiras; possivelmente, para manter e aumentar a frequência de abertura dos portos, seria necessária a modificação da relação econômica entre São Tomé e Príncipe e o reino, como a publicação de leis e alvarás que incentivassem a produção ou com tarifas que beneficiassem a exportação. Todavia, não foi o que ocorreu.

Em 1810, a anuência portuguesa em cooperar para a proibição do tráfico, presente em tratado de aliança assinado com a Inglaterra no Rio de Janeiro, agravou a situação dos domínios que tinham no comércio de escravizados sua principal receita financeira. A arrecadação alfandegária sobre o comércio de escravizados, mesmo em queda, manteve-se como a principal renda, alcançando $85,17 \%$ de toda a arrecadação do período entre 1809 e $1815,{ }^{72}$ sendo que antes fora 93,52\% (entre agosto de 1799 e outubro de 1808). ${ }^{73}$ Mas quando foi possível observar o impacto da proibição inglesa na arrecadação alfandegária de São Tomé e Príncipe?

Percebe-se que o impacto da proibição inglesa na arrecadação alfandegária de São Tomé e Príncipe foi mais forte a partir de 1812, mas ainda com variações (Figura 4). Todavia, como mencionado anteriormente, o declínio econômico da possessão já era percebido nos anos finais do Setecentos. De acordo com Neuma Brilhante, “a franca decadência econômica e populacional” já existia quando D. Rodrigo de

da ilha do Príncipe que foram exportados em 1840 em navios estrangeiros, Ilha do Príncipe, 2 jan. 1841. Já em Angola, a cotação gravitava em torno dos $4 \$ 800$ réis. AHU SEMU-DGU, Angola, nv. 598, pt. 6B, Direitos na Alfândega desta cidade, Luanda, 15 de maio de 1843.

71 Segundo o Ofício Resposta ao Real Aviso de 16 de março de 1808. AHU CU STP, cx. 43, doc. 20, Ofício de $1^{\circ}$ de abril de 1809.

72 Mapas das alfândegas contidos no Segundo Ofício Resposta ao Real Aviso de 16 de março de 1808. AHU CU STP, cx. 43, doc. 20, Ofício de $1^{\circ}$ de abril de 1809. Não encontramos dados referentes ao ano de 1811.

73 AHU CU STP, cx. 43, doc. 20, Ofício de $1^{\circ}$ de abril de 1809. 
Souza Coutinho assumiu a Secretaria de Negócios da Marinha e Domínios Ultramarinos. ${ }^{74}$

O ano com maior impacto foi 1813, momento no qual o saldo das alfândegas de São Tomé ficou negativo e com acentuada queda no saldo da ilha de Príncipe (Figura 5). Foi também em 1813 que se verificaram quedas na receita das alfândegas (Figura 3) e na arrecadação sobre o comércio de escravizados (Figura 4). Provavelmente, vivenciando o que seria constatado em 1813 e em razão das "hostilidades" dos navios ingleses frente às embarcações negreiras portuguesas, ${ }^{75}$ os cidadãos de São Tomé e Príncipe encaminharam uma representação em 12 de março de 1812, na qual relataram: "o triste estado em que se acham estas colônias, o diminuto número de gentes que nelas existem e sem negócio por falta de comércio, principalmente, faltando-nos este único giro que nos servia de proveito, tanto na nossa agricultura como na remessa de alguns ao Brasil”. ${ }^{76}$

O documento assinado por 28 moradores, entre os quais o procurador da câmara, o juiz de órfãos, dois juízes ordinário e três vereadores. ${ }^{77}$ Os assinantes solicitavam a manutenção da graça de comercializar o resgate de escravos desde a ilha de Fernando Pó até o reino do Congo, "assim como nos portos da Costa da Mina, Benim e Onim ou ao menos nestes podermos comerciar em Panos, Marfim, Cera e Azeite [...] na confirmação da Graça implorada constantemente da mesma certidão por quanto nestas ilhas não podemos passar sem escravos principalmente”. ${ }^{78}$

74 Neuma Brilhante, "Nas franjas do império ultramarino português: a experiência insular de São Tomé e Príncipe no despertar dos oitocentos”, História, v. 28, n. 1 (2009), pp. 71-97 ف00.

75 Relato apresentado na representação encaminhada ao governador geral da possessão, Luís Joaquim Lisboa, que a encaminhou em 25 de abril de 1812 ao Conde das Galveias, Secretário de Estado dos Negócios da Marinha e Domínios Ultramarinos. AHU CU STP, cx. 46, doc. 36, Ofício, Ilha de São Tomé, 25 abr. 1812.

76 AHU CU STP, cx. 46, doc. 36, Ofício.

77 AHU CU STP, cx. 46, doc. 36, Ofício.

78 AHU CU STP, cx. 46, doc. 36, Ofício. 
Figura 3

Receita das alfândegas de São Tomé e Príncipe (1809-1815)

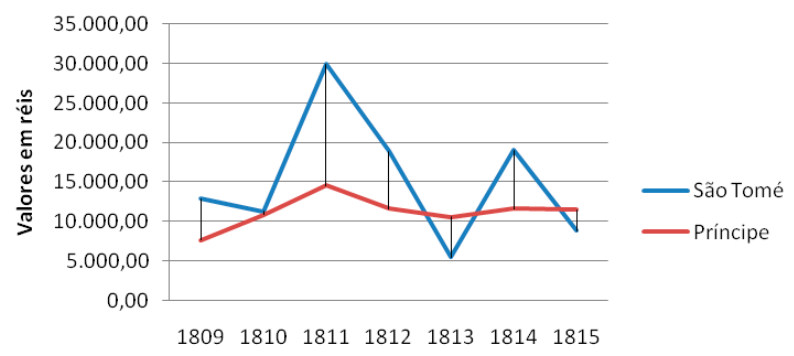

Fonte: Mapas alfandegários em AHU CU STP, cx. 44, doc. 21, Mapas da Receita e Despesa dos Cofres da Fazenda Real destas Ilhas, Ilha do Príncipe, 30 jun. 1810.; cx. 45, doc. 16, Mapas da Receita e Despesa dos Cofres da Fazenda Real destas Ilhas, Ilha de São Tomé, 2 maio 1811; cx. 48, doc. 4, Mapas da Receita e Despesa dos Cofres da Fazenda Real destas Ilhas, Ilha do Príncipe, 29 mar. 1813; cx. 49, doc. 8, Mapas da Receita e Despesa dos Cofres da Fazenda Real destas Ilhas, Ilha do Príncipe; cx. 50, doc. 4, Mapas da Receita e Despesa dos Cofres da Fazenda Real destas Ilhas, Ilha do Príncipe, 13 maio 1815; e cx. 50, doc. 30, Mapas da Receita e Despesa dos Cofres da Fazenda Real destas Ilhas, Ilha do Príncipe, 2 out. 1816. O valor referente à receita do ano de 1811 é de 29:910\$213 réis e não 29:910\$204 réis. Existe um erro na soma dos valores mensais.

Figura 4

Arrecadação alfandegária sobre o comércio de escravizados em São Tomé e Príncipe (1809-1815)

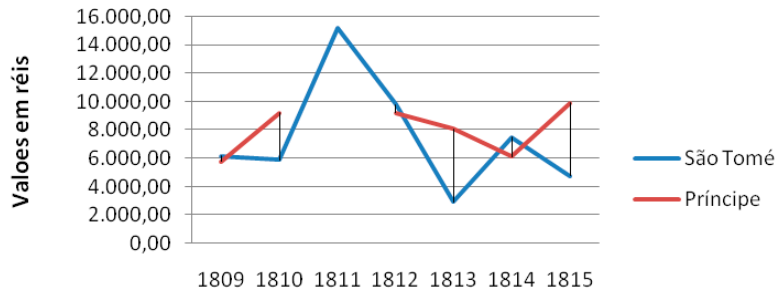

Fonte: Mapas alfandegários em AHU CU STP, cx. 44, doc. 21, Mapas da Receita e Despesa dos Cofres da Fazenda Real destas Ilhas, Ilha do Príncipe, 30 jun. 1810; cx. 45, doc. 16; Mapas da Receita e Despesa dos Cofres da Fazenda Real destas Ilhas, Ilha de São Tomé, 2 maio 1811; cx. 48, doc. 4, Mapas da Receita e Despesa dos Cofres da Fazenda Real destas Ilhas, Ilha do Príncipe, 29 mar. 1813; cx. 49, doc. 8, Mapas da Receita e Despesa dos Cofres da Fazenda Real destas Ilhas, Ilha do Príncipe; cx. 50, doc. 4, Mapas da Receita e Despesa dos Cofres da Fazenda Real destas Ilhas, Ilha do Príncipe, 13 maio 1815; e cx. 50, doc. 30, Mapas da Receita e Despesa dos Cofres da Fazenda Real destas Ilhas, Ilha do Príncipe, 21 out. 1816. Não foram encontrados dados da arrecadação sobre o comércio de escravizados no ano de 1811 em Príncipe. No mapa da arrecadação da receita da alfândega referente ao ano de 1815, a coluna "Direitos reais sobre os escravos" apresenta a soma parcial incorreta; o valor correto é de 9:880\$923 réis e não 12:568\$103 réis. 
Figura 5

Saldos das alfândegas de São Tomé e Príncipe (1809-1815)

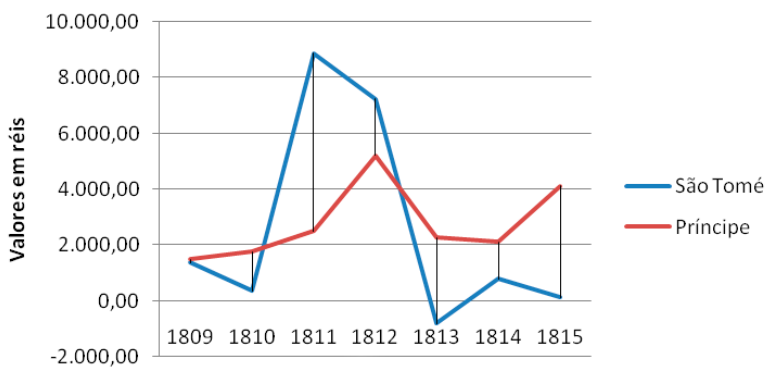

Fonte: Mapas alfandegários em AHU CU - São Tomé e Príncipe. cx. 44, doc. 21, Mapas da Receita e Despesa dos Cofres da Fazenda Real destas Ilhas, Ilha do Príncipe, 30 jun. 1810; cx. 45, doc. 16, Mapas da Receita e Despesa dos Cofres da Fazenda Real destas Ilhas, Ilha de São Tomé, 2 maio 1811; cx. 48, doc. 4, Mapas da Receita e Despesa dos Cofres da Fazenda Real destas Ilhas, Ilha do Príncipe, 29 mar. 1813; cx. 49, doc. 8, Mapas da Receita e Despesa dos Cofres da Fazenda Real destas Ilhas, Ilha do Príncipe; cx. 50, doc. 4, Mapas da Receita e Despesa dos Cofres da Fazenda Real destas Ilhas, Ilha do Príncipe, 13 maio 1815; e cx. 50, doc. 30, Mapas da Receita e Despesa dos Cofres da Fazenda Real destas Ilhas, Ilha do Príncipe, 2 out. 1816.

Dois pontos merecem destaque na representação enviada pelos moradores. Primeiro, a ausência do café no pedido. Se considerarmos a cultura do café como uma condição para a importação de escravizados, ${ }^{79}$ provavelmente, a não citação desse produto na representação ocorreu mediante a impossibilidade do "resgate de escravos". O segundo é, mais uma vez, a dependência do comércio de escravizados, que não só movimentava economicamente a possessão, como também era responsável pelo abastecimento da mão de obra utilizada na agricultura e, por conseguinte, pela produção que começava a sofrer com o desinteresse dos lavradores frente à dificuldade de obter "braços”. Segundo o governador, "alguns habitantes que tiraram todos os seus interesses da cultura dos mantimentos e víveres que [...] permutavam por gêneros que depois em pequenas embarcações conduziam aos portos da Costa da Mina, Benim e Gabão a resgatar escravos que importados para estas ilhas”. ${ }^{80}$

79 Nascimento, “S. Tomé na segunda metade de Oitocentos”, p. 32.

80 AHU CU STP, cx. 43, doc. 20, Ofício de $1^{\circ}$ de abril de 1809. 


\section{Conclusão}

Frente ao declínio econômico vivenciado desde os finais do Setecentos, o café foi apresentado como "alavanca" para a renovação necessitada em São Tomé e Príncipe. Mesmo com certa resistência a sua implantação, a cultura logo no início do século XIX passou a ser um dos sustentáculos econômicos do arquipélago mantendo a visitação de embarcações estrangeiras num período de aumento da demanda pelo grão.

O café, entretanto, não foi suficiente para conter a decadência econômica que se fez sentir, principalmente, a partir de 1813. O abatimento evidenciou a baixa contribuição portuguesa para sua superação, com parca presença de navios "nacionais" e alta taxa para a entrada de produtos oriundos das possessões em África na metrópole. Assim, num cenário de proibição do comércio de escravizados, o café tornou-se o principal atrativo para manter o interesse das embarcações estrangeiras pelo arquipélago, que terminavam por garantir o abastecimento de gêneros de primeira necessidade.

Com produção baseada na mão de obra escrava e tendo grande quantitativo de trabalho feminino - o que a diferenciava da colônia portuguesa na América -, a lavoura cafeeira no arquipélago se expandiu frente à retração do tráfico e devido ao baixo custo da terra. Percebe-se ainda que os principais lavradores, categorizados pelo quantitativo de escravizados e não a partir da produção agrícola, não foram os encarregados imediatos pelo cultivo do café - plantio desenvolvido pelos pequenos proprietários.

Com o café assumindo a função de substituto econômico dos negócios que sustentavam os habitantes do arquipélago ${ }^{81}$ e a conexão econômica da possessão com a metrópole passando pela oferta do grão, ${ }^{82}$ os produtores de café, ou seja, os pequenos proprietários foram fundamentais para o desenvolvimento do processo de exportação, por conseguinte, pela visitação das embarcações estrangeiras e pelo abastecimento dos gêneros

81 Nascimento, “S. Tomé e Príncipe no século XIX”, p. 99

82 Nascimento, “S. Tomé na segunda metade de Oitocentos”, p. 23. 
mais necessários. Dessa forma, foram os responsáveis diretos por iniciar o processo de retomada do vigor na relação comercial com a metrópole.

Recebido em 11 ago. 2020 Aprovado em 24 nov. 2020

doi: 10.9771/aa.v0i63.38370 
Este artigo aborda a cultura cafeeira em São Tomé e Príncipe durante o período imediatamente posterior à proibição inglesa do comércio de escravizados em 1807. Considerada a cultura capaz de desenvolver a agricultura no arquipélago, o café, apesar da resistência inicial ao seu cultivo, manteve o interesse e a presença de embarcações estrangeiras quando da interdição inglesa e da isenção de ancoragem concedida pela Coroa portuguesa a todos os navios do Brasil que comercializavam na Costa da Mina; desde que fossem recolhidos os direitos aos portos onde ocorreram as barganhas comerciais. Beneficiando-se da demanda existente e da qualidade, o grão aos poucos conquistou o interesse e foi apontado como a cultura que ajudaria a superar o cenário de proibição do comércio de sua maior receita alfandegária até então, o comércio de escravizados.

\section{Café | São Tomé e Príncipe | Tráfico de escravizados}

\section{The Importance of Coffee for São Tomé and Príncipe in View of the Prohibition of SlaVe Trade by ENGLAND}

This article addresses coffee farming in São Tomé and Príncipe just after the English ban on the slave trade in 1807. Considered a key crop for of the development of agriculture in the archipelago, despite initial resistance to its cultivation, coffee maintained foreign commerce when the English ban and the anchorage exemption granted by the Portuguese crown to Brazilian ships trading in the Costa da Mina provided rights to the ports where the commercial bargains occurred. Benefiting from the demand for quality coffee beans, the crop gradually won the interest of local producers seeking to overcome the negative economic impact of the ban on the islands' largest source of customs revenue: the commerce in enslaved people.

Coffee | Sao Tomé and Príncipe | Slave trade 